\title{
TINGKAT PENGETAHUAN MASYARAKAT TERHADAP KEBERADAAN DAN PENYEBAB KERUSAKANSUMBERDAYA AIR SUNGAI BAWAH TANAH DI KAWASAN KARST GUNUNGSEWU
}

\author{
Oleh: \\ Ahmad Cahyadi \\ Jurusan Geografi Lingkungan Fakultas Geografi Universitas Gadjah Mada \\ ahmadcahyadi@geo.ugm.ac.id
}

\begin{abstract}
Abstrak
Informasi terkait dengan tingkat pengetahuan masyarakat terhadap keberadaan dan penyebab kerusakan sumberdaya air sungai bawah tanah di kawasan karst sangat penting. Hal ini mengingat informasi tersebut akan menjadi informasi yang sangat berharga untuk mendukung rencana pengelolaan kawasan karst khususnya konservasi sungai bawah tanah. Penelitian ini bertujuan untuk mengetahui tingkat pengetahuan masyarakat terhadap keberadaan dan penyebab kerusakan sumberdaya air sungai bawah tanah di Kecamatan Saptosari, Kabupaten Gunungkidul, Daerah Istimewa Yogyakarta. Metode yang digunakan dalam penelitian ini adalah wawancara mendalam pada beberapa lokasi yang dipilih secara purposive sampling. Analisis data dilakukan secara deskripstif kualitatif. Hasil penelitian menunjukkan bahwa masyarakat di lokasi kajian memiliki pengetahuan tentang keberadaan sungai bawah tanah di kawasan karst. Namun demikian, tingkat pengetahuan tentang penyebab kerusakan sumberdaya air sungai bawah tanah belum banyak diketahui. Kondisi ini disebabkan oleh karena pengetahuan masyarakat tentang sungai bawah tanah masih rendah. Oleh karena itu, maka upaya konservasi sungai bawah tanah di lokasi kajian sebaiknya di awali dengan melakukan penyuluhan tentang karakteristik wilayah karst termasuk sungai bawah tanah.
\end{abstract}

Kata Kunci : Tingkat Pengetahuan, Pengelolaan, Sungai Bawah Tanah, Karst, Gunungkidul

\section{Informationrelated to thelevel of public knowledgeof the} existenceandcausedamage towater resourcesin the underground river of karst area are very important. This is because this information would be very valuable information to support the management plan of karstic underground river conservation in particular. This study aims to determine the of the existenceandcausedamage towater resourcesin the underground river, the District Saptosari, Gunungkidul Regency, Yogyakarta Special Region. The method used in this study is in-depth interviews at several locations selected by purposive sampling. TechniThe results showedthatthe communities inthe studyhadknowledgeof the existence ofan underground riverin the karst region. However, the level ofknowledgeabout the causes ofdamage toundergroundwater resourcesof the riverhas not been known. This condition iscaused by thepublic's knowledge ofthe underground riveris still low. Therefore, the karstic underground river conservation efforts at the site of the study should be starting to do counseling on the characteristics of karst areas including underground river.

Keywords :Level of Knowledge, Management, Undergroun River, Karst, Gunungkidul

\section{Pendahuluan}

Kawasan karst merupakan bentanglahan yang terbentuk oleh proses interaksi antara air, udara (Karbondioksida) dan batuan yang mudah larut (Domenico dan 
Tingkat Pengetahuan Masyarakat Terhadap Keberadaan dan Penyebab Kerusakan Sumberdaya Air Sungai Bawah Tanah di Kawasan Karst Gunungsewu

Schwartz, 1990; Ford dan Williams, 1992; 2007). Proses interaksi tersebut menyebabkan terjadinya proses pelarutan batuan yang kemudian menghasilkan suatu kondisi hidrologi yang unik (Cahyadi, 2010). Lorong-lorong hasil pelarutan yang terbentuk di kawasan karst menyebabkan air permukaan cepat teratus menuju ke sistem sungai bawah tanah (Thornbury, 1958). Hal ini menyebabkan kondisi kering di permukaan dan kaya air di bagian bawah permukaan (Rosaji dan Cahyadi, 2012).

Salah satu kawasan karst yang terdapat di Indonesia adalaha Kawasan Karst Gunungsewu (Gambar 1). Kawasan ini membentang dari dari Kabupaten Gunungkidul di bagian Barat sampai dengan Kabupaten Pacitan di Bagian Timur. Kawasan Karst Gunungsewu meliputi tiga kabupaten (Kabupaten Gunungkidul, Kabupaten Wonogiri dan Kabupaten Pacitan) serta meliputi tiga provinsi (Daerah Istimewa Yogyakarta, Provinsi Jawa Tengah dan Provinsi Jawa Timur) dengan luas sekitar 1.300 km² (Haryono dkk, 2009).

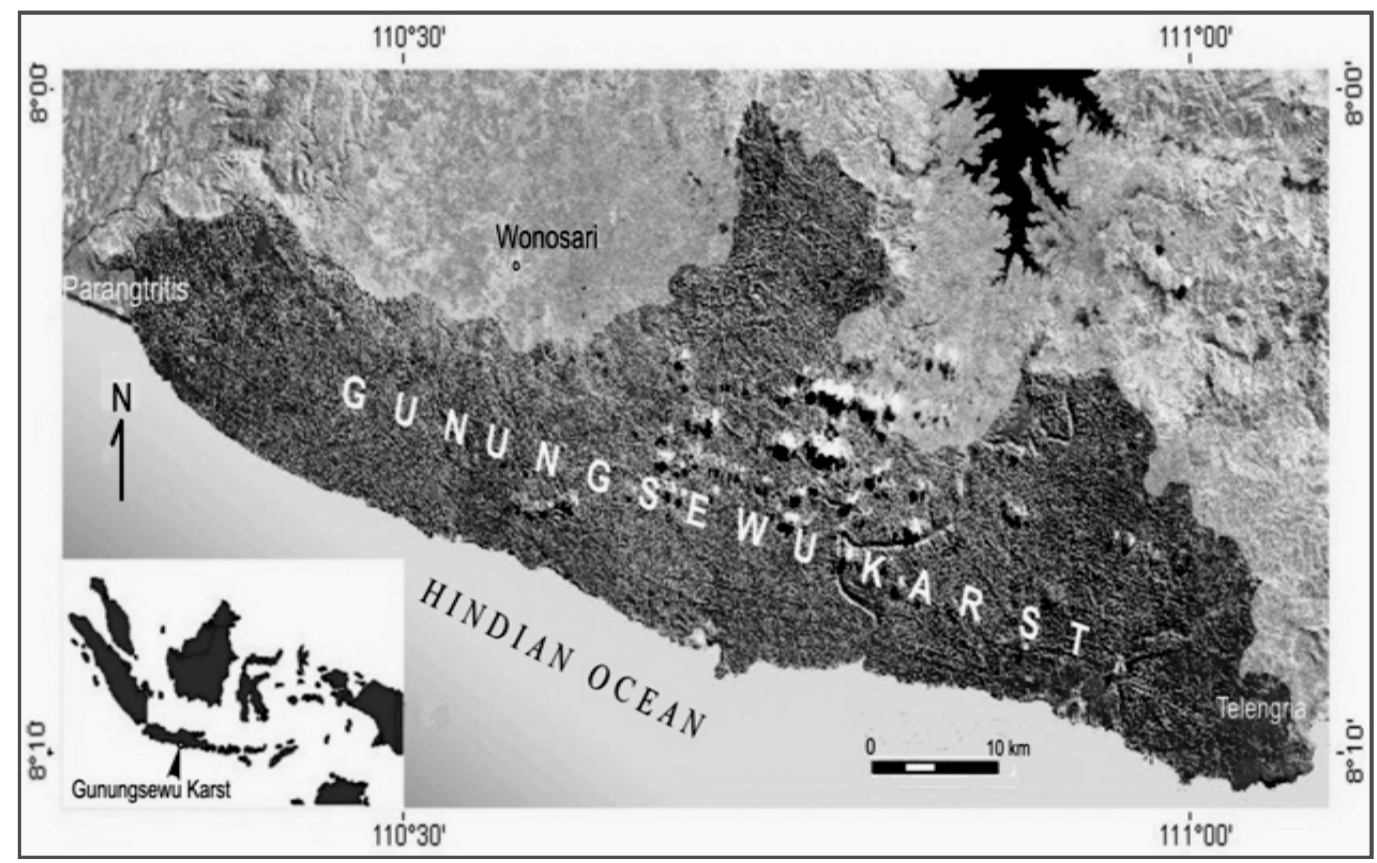

Gambar 1. Citra Landsat Kawasan Karst Gunungsewu (Haryono, dkk. 2009)

Kawasan Karst Gunungsewu merupakan salah satu kawasan yang dikenal sering mengalami bencana kekeringan (White, 1988). Kondisi ini salah satunya disebabkan karena sumberdaya air permukaan yang terdapat di kawasan ini sangat terbatas. Sumber air permukaan di kawasan ini berupa telaga dan mataair. Saat ini kondisi banyak telaga di Kawasan Karst Gunungsewu telah mengalami degradasi, baik dalam hal kuantitas ataupun dalam hal kualitas. Aspek kuantitas potensi telaga meliputi jumlah air yang ditampung suatu telaga, lamanya kemampuan telaga menampung air setelah musim penghujan berakhir, dan jumlah telaga yang tidak mati (tertutup sedimen).

Ketergantungan masyrakat terhadap sumberdaya air di telaga kawasan karst untuk memenuhi kebutuhan domestik dahulu sangatlah tinggi, yakni mencapai $80 \%$. Namun demikian, hasil survei yang dilakukan oleh Cahyadi, dkk. (2011) menyebutkan bahwa tingkat ketergantungan masyarakat terhadap sumberdaya air dari telaga di Kawasan Karst 
Gunungsewu telah banyak berkurang. Hal ini disebabkan karena pemenuhan kebutuhan air domestik masyarakat telah dicukupi dengan jaringan PDAM yang menyalurkan air yang berasal dari sungai bawah tanah.

Peranan sungai bawah tanah dalam pemenuhan kebutuhan air domestik di Kawasan Karst Gunungsewu khusunya di Kabupaten Gunungkidul sangatlah besar (Tabel 1). PDAM di Kabupaten Gunungkidul disuplai oleh empat sistem yang kesemuanya berasal dari sungai bawah tanah kawasan karst. Empat sistem yang berfungsi menyuplai PDAM adalah sistem Bribin, Sistem Baron, Sistem Ngobaran dan Sistem Seropan. Air yang berasal dari sungai bawah tanah kawasan karst ini tidak hanya mensuplai kebutuhan air di Kawasan Karst Gunungsewu, tetapi juga mensuplai kebutuhan air di Ledok Wonosari.

Tabel 1. Sistem Pensuplai Air PDAM di Gunungkidul dan Besarnya Kapasitas Pelayanan

\begin{tabular}{|l|l|c|c|c|}
\hline \multicolumn{1}{|c|}{ Sistem } & \multicolumn{1}{|c|}{ Daerah Pelayanan } & Jumlah & $\begin{array}{c}\text { Jumlah } \\
\text { SSRT }\end{array}$ & $\begin{array}{c}\text { Jumlah Dusun/ Desa } \\
\text { yang Terlayani }\end{array}$ \\
\hline $\begin{array}{l}\text { Bribin } \\
\text { dan 2 } 1\end{array}$ & $\begin{array}{l}\text { Kecamatan Semanu, } \\
\text { Tepus, Rongkop, dan } \\
\text { Girisubo }\end{array}$ & 510 & 7.387 & $\begin{array}{c}134 \text { dusun; } \\
21 \text { desa }\end{array}$ \\
\hline Seropan & $\begin{array}{l}\text { Kecamatan Semanu, } \\
\text { Ponjong, Karangmojo, dan } \\
\text { Wonosari }\end{array}$ & 115 & 7.292 & $\begin{array}{c}134 \text { dusun; } \\
21 \text { desa }\end{array}$ \\
\hline Baron & Kecamatan Tanjungsari & 57 & 874 & $\begin{array}{c}32 \text { dusun; } \\
\text { 4 desa }\end{array}$ \\
\hline Ngobaran & $\begin{array}{l}\text { Kecamatan Saptosari, } \\
\text { Purwosari dan Panggang }\end{array}$ & 180 & 6.811 & $\begin{array}{c}152 \text { dusun; } \\
40 \text { desa }\end{array}$ \\
\hline
\end{tabular}

Sumber : Suryono, 2006

Keterangan:

SHU: Sambungan Hidran Umum

SSRT: Sambungan Saluran Rumah Tangga

Besarnya kontribusi sungai bawah tanah di kawasan karst Gunungkidul menjadikan pengelolaan sumberdaya air di dalamnya khususnya di sungai bawah tanah menjadi sangat penting. Salah satu hal yang perlu mendapatkan perhatian lebih adalah pencegahan terjadinya pencemaran dari aktivitas manusia di bagian permukaan yang merupakan wilayah tangkapan air dari sungai bawah tanah di Kawasan Karst Gunungsewu memiliki kerentanan airtanah terhadap pencemaran yang tinggi (Cahyadi dan Hartoyo, 2011).

Kerentanan airtanah adalah kemudahan airtanah di suatu wilayah untuk tercemar oleh suatu polutan (Vrbadan Zoporozec, 1994). Tingginya kerentanan airtanah di kawasan karst disebabkan air permukaan yang membawa polutan dapat masuk langsung ke dalam sistem sungai bawah tanah dengan proses penyaringan oleh tanah yang sangat minimal atau bahkan tanpa terjadi proses penyaringan oleh tanah karena air permukaan masuk melalui lorong-lorong konduit (Veni dan DuCene, 2001).

Penelitian ini bertujuan untuk mengetahui tingkat pengetahuan mesyarakat terhadap keberadaan dan penyebab kerusakan sumberdaya air di sungai bawah tanah di 
kawasan karst Gunungkidul, khususnya di Kecamatan Saptosari. Lokasi kajian mengambil studi kasus di kawasan karst di Kecamatan Saptosari Kabupaten Gunungkidul. Lokasi ini menurut Cahyadi dan Hartoyo (2011) memiliki kerentanan airtanah terhadap pencemaran tinggi (Gambar 2). Selain itu, lokasi kajian merupakan daerah tangkapan air sungai bawah tanah Ngobaran yang merupakan salah satu sistem sungai bawah tanah yang digunakan untuk mensuplai air dari PDAM.

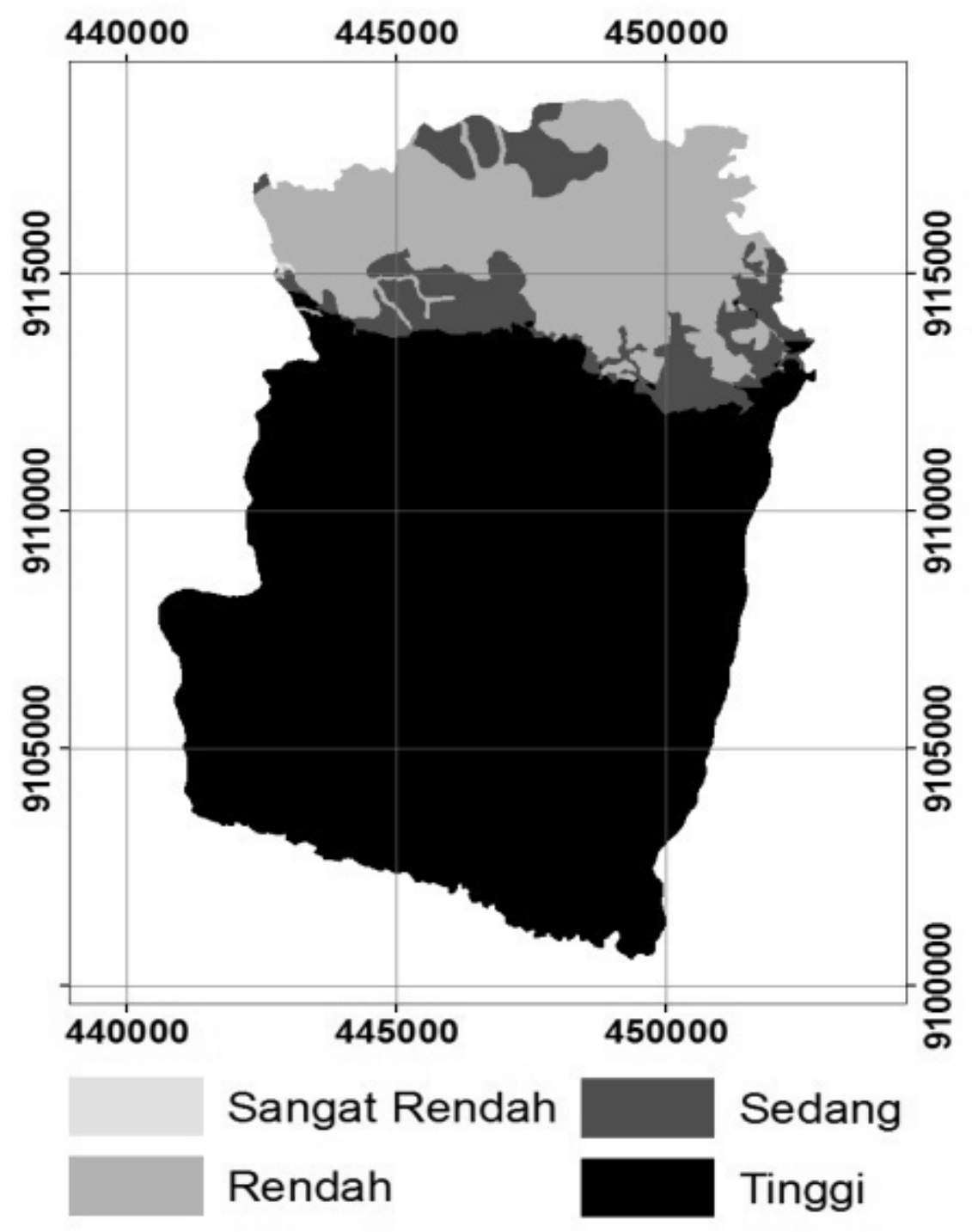

Gambar 2. Peta Kerentanan Airtanah di Kecamatan Saptosari (Bawah) dan Paliyan (Bagian Atas). (Sumber: Cahyadi dan Hartoyo, 2011)

Penelitian terkait dengan pengetahuan masyarakat terhadap tingkat pengetahuan masyarakat terhadap lingkungan sungai bawah tanah kawasan karst menjadi sangat penting mengingat tingkat pengetahuan masyarakat terkait hal tersebut akan mempengaruhi perilaku yang terkait aktivitas-aktivitas pemanfaatan kawasan karst. Hal ini tertunya berpengaruh pula pada hal-hal yang dapat menyebabkan kerusakan lingkungan seperti perilaku pemanfaatan lahan, pembuangan limbah, pengelolaan sanitasi dan 256 
perilaku terhadap pemanfaatan sumber air. Selain itu, data terkait tingkat pengetahuan masyarakat terhadap pengelolaan lingkungan sungai bawah tanah dapat digunakan sebagai masukan dalam menyusun strategi pengelolaan wilayah lingkungan DTA sungai bawah tanah di kawasan karst khususnya di DTA Sungai Bawah Tanah Ngobaran.

\section{Metode Penelitian}

Penelitian ini dilakukan dengan wawancara mendalam (in-depth interview) yang dilakukan terhadap rsponden pada blok-blok permukiman terpilih di lokasi kajian. Blokblok permukiman yang dipilih merupakan blok-blok permukiman dengan luas paling besar sampai dengan luas terbesar kesepuluh berdasarkan peta penggunaan lahan yang diambil dari peta Rupa Bumi Indonesia skala 1:25.000. Teknik pengambilan sampel dilakukan dengan stratified random sampling. Masing-masing blok permukiman diambil delapan responden untuk dilakukan wawancara mendalam, sehingga jumlah responden secara keseluruhan adalah 80 orang. Analisis data dilakukan dengan statistik deskriptif terhadap data hasil wawancara.

\section{Hasil Penelitian dan Pembahasan}

Responden yang diwawancarai pada penelitian ini dikelompokkan menjadi lima kelompok umur. Lima kelompok umur tersebut yaitu umur 20 - 30 tahun, $30-40$ tahun, 40 - 50 tahun, 50 - 60 tahun dan > 60 tahun. Beradasarkan kelompok tersebut, maka terdapat variasi umur yang cukup jauh, namun memiliki kelebihan bahwa tidak terdapat responden yang belum dewasa. Hal ini sangt penting mengingat kelompok umur tersebut merupakan kelompok umur yang saat ini merupakan pelaku utama dari semua aktivitas manusia di wilayah kajian. Tabel 2. menunjukkan bahwa responden dalam penelitian ini didominasi oleh kelompok umur 40 - 50 tahun.

Tabel 2. Jumlah Responden pada Masing-Masing Kelompok Umur

\begin{tabular}{|c|c|c|}
\hline Kelompok Umur & Jumlah & $\%$ \\
\hline 20-30 Tahun & 18 & 22,5 \\
\hline 30-40 Tahun & 24 & 30,0 \\
\hline 40-50 Tahun & 27 & 33,8 \\
\hline 50-60 Tahun & 7 & 8,8 \\
\hline$>$ 60 Tahun & 4 & 5,0 \\
\hline Jumlah & 80 & 100 \\
\hline
\end{tabular}

Sumber: Hasil Analisis Data wawancara

Hasil wawancara menunjukkan bahwa responden dalam penelitian ini didominasi oleh responden dengan mata pencaharian/ pekerjaan petani (Tabel 3). Jumlah responden petani sejumlah 57 orang atau 71,3 5 dari total responden. Pekerjaan responden terbanyak berikutnya secara berturut-turut adalah Pegawai Negeri Sipil (PNS), Wiraswasta (bidang jasa), Pedagang dan Pegawai pemerintah desa (non PNS). 
Tabel 3. Distribusi Pekerjaan Responden

\begin{tabular}{|l|c|c|}
\hline \multicolumn{1}{|c|}{ Pekerjaan } & Jumlah & $\%$ \\
\hline Petani & 57 & 71,3 \\
\hline Pedagang & 5 & 6,3 \\
\hline Wiraswasta & 7 & 8,8 \\
\hline PNS & 8 & 10,0 \\
\hline Pegawai Pemerintah Desa & 3 & 3,8 \\
\hline Jumlah & 80 & 100 \\
\hline
\end{tabular}

Sumber: Hasil Analisis Data Wawancara

Berdasarkan tingkat pendidikannya, maka responden dapat dikelompokkan menjadi lima kelas. Tingkat pendidikan didominasi oleh responden dengan responden dengan tingkat pendidikan rendah (tidak sekolah atau tidak tamat sekolah dasar (SD)). Responden dengan kelas tersebut hampir mencapai separuh responden (47,5\%). Tingkat pendidikan terbanyak berikutnya secara berurutan adalah SD, sekolah menengah atas (SMA), Sarjana, dan sekolah menengah pertama (SMP). Responden dengan tingkat pendidikan sarjana kesemuanya adalah pegawai negeri sipil yang bekerja sebagai guru.

Tabel 4. Distribusi Tingkat Pendidikan Responden

\begin{tabular}{|l|c|c|}
\hline \multicolumn{1}{|c|}{ Pendidikan } & Jumlah & \% \\
\hline Tidak Sekolah & 38 & 47,5 \\
\hline SD & 19 & 23,8 \\
\hline SMP & 6 & 7,5 \\
\hline SMA & 9 & 11,3 \\
\hline Sarjana & 8 & 10,0 \\
\hline Jumlah & 80 & 100 \\
\hline
\end{tabular}

Sumber: data primer

Hasil wawancara menunjukkan bahwa semua responden mengerti bawah sungai bawah tanah terdapat di wilayah penelitian. Semua responden menjadikan sungai bawah tanah yang terdapat di Ngobaran sebagai contoh keberadaan sungai bawah tanah di lokasi kajian. Selain itu, sejumlah 42 orang (52,5\%) responden menambahkan sungai bawah tanah yang terdapat di Bribin atau Baron sebagai contoh keberadaan sungai bawah tanah di lokasi kajian. Berdasarkan hasil tersebut berarti bahwa masyarakat telah mengetahui keberadaan sungai bawah tanah di lingkungan sekitar mereka.

Pengetahuan tentang keberadaan sungai bawah tanah lebih banyak diperoleh dari berita baik pada surat kabar, radio ataupun televisi. Hal tersebut nampak dari keseluruhan responden yang menyatakan demikian, sedangkan responden yang menyatakan mengetahui keberadaan sungai bawah tanah dari media dan pengalaman melihat sendiri hanya sejumlah 38 orang (47,5\%). Kondisi ini mencerminkan banyaknya masyarakat yang belum benar-benar melihat dan mengetahui betul tentang wujud dari sungai bawah tanah meskipun sungai bawah tanah tersebut berada di sekitar lingkungan mereka. Hal ini disebabkan akses terhadap sungai bawah tanah seringkali diketemukan pada lokasi yang jauh dari permukaan dan atau akses menuju tempat tersebut cukup sulit. 
Tingkat pengetahuan masyarakat terkait dengan arti penting sungai bawah tanah adalah tinggi. Hal ini tampak dari pemahaman masyarakat tentang pemanfaatan sungai bawah tanah sebagai sumber air yang digunakan oleh PDAM Sistem Ngobaran. Namun demikian, pengetahuan masyarakat terkait dengan bagaimana sungai bawah tanah dapat terbentuk di wilayah tersebut, bagaimanakah kondisi sistem sungai bawah tanah dan sumber air yang mensuplai sungai bawah tanah tidak dipahami oleh seluruh responden. Kondisi ini menyebabkan pemahaman masyarakat terhadap hal-hal yang dapat menyebabkan kerusakan atau pencemaran sumberdaya air di sungai bawah tanah tidak banyak diketahui masyarakat. Responden yang dapat menjawab dengan benar terkait dengan hal-hal yang dapat menyebabkan pencemaran sumberdaya air di sungai bawah tanah hanya 18 responden $(22,5 \%)$.

Pemahaman terkait hal-hal yang dapat menyebabkan pencemaran sumberdaya air di sungai bawah tanah yang rendah kemudian menyebabkan banyak aktivitas masyarakat yang tidak mengindahkan kaidah konservasi sumberdaya air sungai bawah tanah. Hal ini misalnya nampak dari perlakuan terhadap luweng (gua vertikal) sebagai tempat pembuangan sampah, pemanfaatan lahan di sekitar luweng untuk pertanian yang kemudian menyebabkan pencemaran air sungai bawah tanah dari pupuk, pestisida dan sedimen yang terangkut akibat erosi serta pembuatan sanitasi yang kurang ramah lingkungan. Kondisi sanitasi yang dimaksud adalah berupa pembuangan limbah cuci dan mandi (grey water) dan pembuangan limbah kakus (black water) dengan fasilitas sanitasi yang masih memungkinkan terjadinya peresapan air limbah meresap ke dalam sistem sungai bawah tanah dengan penyaringan yang minimal oleh tanah dan batuan di kawasan karst (Leibundgut, 1998).

Pemahaman yang rendah terkait dengan sungai bawah tanah juga menyebabkan pengetahuan masyarakat terkait dengan hal-hal yang harus dilakukan untuk dapat mengelola dan menjaga kelestarian sumberdaya air sungai bawah tanah menjadi rendah pula. Hal ini nampak pada seluruh responden yang seakan tidak memiliki ide untuk dapat mengelola sumberdaya sungai bawah tanah. Responden beralasan letak sungai bawah tanah yang sulit dijangkau dan tidak diketahui sistem alirannya akan menyebabkan pengelolaan dan konservasi sumberdaya air di sungai bawah tanah akan sulit untuk dilakukan. Hal ini menunjukkan pemahanan masyarakat tentang sistem sungai bawah permukaan di kawasan karst yang sangat terkait dengan kondisi di atas permukaan tanah belum dipahami dengan baik.

\section{Kesimpulan}

Berdasarkan hasil analisis data wawancara yang telah dilakukan, maka diketahui bahwa pengetahuan masyarakat di lokasi kajian terhadap keterdapatan dan arti penting sungai bawah tanah sudah tinggi, namun demikian pemahaman terkait sistem, keberadaan dan faktor yang dapat menyebabkan terjadinya pencemaran sumberdaya air di sungai bawah tanah masih rendah. Hal ini kemudian menyebabkan banyak aktivitas yang berpotensi menyebabkan kerusakan sumberdaya air di sungai bawah tanah seperti pemanfaatan luweng sebagai tempat sampah, pemanfaatan lahan di sekitar luweng untuk pertanian yang berpotensi menyebabkan pencemaran air dari pupuk dan pestisida serta 
Tingkat Pengetahuan Masyarakat Terhadap Keberadaan dan Penyebab Kerusakan Sumberdaya Air Sungai Bawah

Tanah di Kawasan Karst Gunungsewu

kondisi sanitasi grey water dan black water yang kurang ramah lingkungan. Oleh karena itu, maka diperlukan sosialisasi dan pendidikan terhadap masyarakat untuk dapat memberikan pemahaman tentang sungai bawah tanah, karakteristik hidrologi kawasan karst, hal-hal yang dapat menyebabkan kerusakan sumberdaya air sungai bawah tanah serta hal-hal yang dapat dilakukan untuk mengkonservasi sumberdaya air di sungai bawah tanah. Kegiatan tersebut harus dilakukan secara bersama-sama seluruh elemen masyarakat dan pemerintah yang dibantu oleh lembaga sosial masyarakat dan akademisi.

\section{Daftar Pustaka}

Cahyadi, A. 2010. Pengelolaan Kawasan Karst dan Peranannya dalam Siklus Karbon di Indonesia.Proseeding Seminar Nasional Perubahan Iklim di Indonesia.Sekolah Pasca Sarjana UGM Yogyakarta.

Cahyadi, A.; Wacano, D.; Fatchurohman, H. dan Ramdani, M.A.A. 2011. Peran Telaga Dalam Pemenuhan Kebutuhan Air Di Kawasan Karst Gunungsewu Kecamatan Semanu Kabupaten Gunungkidul Pasca Pembangunan Jaringan Air Bersih. Laporan Penelitian. Karst Student Forum (KSF) Fakultas Geografi Universitas Gadjah Mada.

Cahyadi, A. dan Hartoyo, F.A. 2011.Pemanfaatan Sistem Informasi Geografis (SIG) untuk Pemetaan Wilayah Imbuhan Airtanah dan Kerentanan Airtanah di Kawasan Karst (Studi Kasus di kecamatan paliyan dan Panggang Saptosari, Kabupaten Gunungkidul. Makalah dalam Seminar Nasional Aplikasi Teknologi Informasi 2011 (SNATI 2011) 17-18 Juni 2011, Universitas Islam Indonesia Yogyakarta.

Domenico,P.A. dan Schwartz, F.W. 1990. Physical and Chemical Hydrogeology. Edisi Kedua. New York: John Wiley \& Sons.

Haryono, E.; Adji, T.N.; Widyastuti, M.; Trijuni, S. 2009. Atmospheric Carbon Dioxide Sequestration Trough Karst Denudation Process, Preliminary Estimation From Gunung Sewu Karst. Makalah dalamAchieving Resilient-Agriculture to Climate Change Through the Development of Climate-Based Risk Management Scheme. Bogor: PERHIMPI.

Ford, D. dan Williams, P. 1992. Karst Geomorphology and Hydrology. London: Chapman and Hall.

Ford, D. dan Williams, P. 2007. Karst Geomorphology and Hydrology. West Sussex: John Wiley and sons, inc.

Leibundgut, C. 1998. Karst Hydrology. Proceedings of Workshop W2, no. 247. Rabat, Maroco: IAHS Publication.

Rosaji, F.S.C. dan Cahyadi, A. 2012. DeteksiTelagaPotensialuntukPemenuhanKebutuhan AirMusimKemarau diKawasan KarstMenggunakan Data Penginderaan Jauh Multitemporal. Makalah dalam Simposium Nasional Sains Informasi Geografis. Fakultas Geografi UGM Yogyakarta.

Suryono, T. 2006. Pengelolaan Sumber Air Bawah Tanah Sungai Bribin. Gunung Sewu Indonesian Cave and Karst Journal. Vol. 2(1). Hal: 37-52.

Thornbury, W. D. 1958. Principles of Geomorpholohy. New York: John Wilay and Sons, Inc.

White, W.B. 1988.Geomorphology and Hydrology of Karst Terrains. New York: Oxford University Press.

Veni, G. dan DuChene, H. 2001. Living With Karst: A Fragile Foundation. Alexandria: American Geological Institute.

Vrba, J dan Zoporozec, A. 1994. Guidebook on Mapping Groundwater Vulnerability. Hannover : International Association of Hydrogeologist. 